$\xi=\mathbf{p}$

\title{
Application of HACCP in an Indonesian halal restaurant by incorporating halal dietary requirements
}

\author{
Bernard C. Jiang *, Halim Pratama Putra \\ Department of Industrial Management, School of Management, National Taiwan University of Science and Technology, Taipei, Taiwan \\ *Corresponding author E-mail: halimpratama21@gmail.com
}

\begin{abstract}
This study investigates the safety of ayam lalapan food processing in the catering service, and considers Halal dietary requirements due to the increasing demand for Halal food. Hazard and Haram Analysis Critical Control Point (HHACCP) proposed by Kohilavani et al. [1] is used to analyze the potential hazards as well as to improve the safety of food processing. By using this method, the presence of haram substance is analyzed aside from the regular hazard analysis, which consists of biological, chemical and physical hazards. Critical control points and Halal critical control points are identified to guarantee that the food processing of ayam lalapan meets Halal dietary requirements and is safe for human consumption. The total risk level after improvement can be reduced by $75.64 \%$ from 1.05 to 0.29 compared to before improvement.
\end{abstract}

Keywords: Catering Service; Halal Dietary Requirements; HHACCP; Presence of Haram Substance.

\section{Introduction}

As the final stage in the food chain, the catering service is a critical sector before the consumer consumes the product. One of the quality management systems to ensure food safety is Hazard Analysis and Critical Control Points (HACCP). HACCP is a method to eliminate or prevent hazards to maintain an acceptable level, by proposing several control measures through analyzing potential hazards at each process step.

The increasing demand for Halal food led to increasing numbers of catering services providing Halal food. According to the Pew Research Center in 2015 [2], the Muslim population in 2010 was $23.2 \%$ of the world population and in 2050 will reach $29.7 \%$ of the world population, which shows an increase of $6.5 \%$. This issue raises a new problem: since Halal food must meet certain criteria under Halal dietary requirements, special attention must be put to ensure that the served food does meet these requirements.

Halal food is defined as raw materials used in the production process that are permitted under Sharia law, and meets six following conditions [3]. First, the food and its ingredients may not contain any parts or products of animals that are non-halal by Sharia law, or were not slaughtered according to Sharia law. The second condition is that the raw materials do not contain najs (an Arabic term which means "filth") in any quantity. The third condition is that the food is safe for consumption, non-poisonous, non-intoxicating and non-hazardous to health. The fourth condition explains that the product should be prepared, processed or manufactured using equipment that is not contaminated with najs. The fifth condition states that the food may not contain any human parts or derivatives. The sixth condition is the need for full segregation from any other food and materials that do not meet the requirements stated in the first five conditions during its preparation, processing, handling, packaging, storage and distribution.

Unfortunately, the classic HACCP was introduced to ensure food safety by only analyzing three main hazards: biological, chemical and physical hazard. In 2013, Kohilavani et al. [1] introduced Hazard and Haram Analysis Critical Control Point (HHACCP), a new approach of HACCP, by incorporating the presence of haram substances as part of hazard analysis to deal with the Halal dietary requirements problem.

Many small businesses, like catering services, are not ready to implement HACCP methodology due to the lack of preparation or strong foundation of a prerequisite program. Mortimore and Wallace [4] explained that although we don't have any prerequisite program, we can start from the first principle of the HACCP, which is hazard analysis. It can provide us with some benefits by knowing the potential hazards in the process so that we can undertake some preventive actions to control incoming hazards. This paper will show the implementation of HACCP by considering Halal dietary requirements in the production process of Ayam Lalapan at an Indonesian Halal restaurant in Taipei.

\section{Objectives}

The objectives of this study are described as follows.

1) Fulfilling Halal dietary requirements in the food processing of ayam lalapan by incorporating Halal dietary requirements into Hazard Analysis and Critical Control Point (HACCP).

2) Using Hazard and Haram Analysis Critical Control Point to ensure that the delivered food is safe for consumption and also meet Halal dietary requirements.

\section{Methods}

Hazard and Haram Analysis Critical Control Point (HHACCP) proposed by Kohilavani et al. (2013) [1] is used to analyze the hazards at each process step of ayam lalapan processing. A modular process flow diagram is used to construct the process flow diagram. By using a modular approach, the process can be divided 
into different parts and looked at in detail [4]. The hazard evaluation model is derived from the original model proposed by the National Advisory Committee on Microbiological Criteria for Foods (NACMCF) [5]; some changes have been made in this study in order to assess the presence of haram substances and to accommodate catering service environments. In the proposed hazard characteristics, hazard characteristic A has been omitted because the food is not consumed by at-risk populations such as infants and the aged. Because in this study the consumers directly consume the food after processing, hazard characteristic $\mathrm{F}$ is also omitted since it considers any control step after packaging and distribution to the customers. In the proposed hazard characteristic, we also consider another hazard, which is the presence of haram substances. Proposed hazard characteristics for biological, chemical, physical hazard, and the presence of haram substances can be seen in Table 1. The risk level of each hazard is then calculated based on the results of the assessed hazard characteristics. Furthermore, we can classify the effect of hazards on each process by averaging the risk level of the associated hazards. The risk level and the effect of hazard on each process can be seen in Table 2 and Table 3, respectively. The highest number indicates the highest risk that should be considered.

Table 1: Proposed Hazard Characteristics for Potential Hazard (Biological, Chemical, and Physical Hazard) and Presence of Haram Substance

\begin{tabular}{|c|c|c|}
\hline $\begin{array}{l}\text { Hazard Char- } \\
\text { acteristics }\end{array}$ & $\begin{array}{l}\text { Potential Hazard (Biologi- } \\
\text { cal, Chemical, And Physical } \\
\text { Hazard) }\end{array}$ & $\begin{array}{l}\text { Presence of Haram } \\
\text { Substance }\end{array}$ \\
\hline A & $\begin{array}{l}\text { The product (raw material, } \\
\text { work in process product, or } \\
\text { finished product) contains } \\
\text { potential hazard known as } \\
\text { microbiological hazard, } \\
\text { chemical hazard and physi- } \\
\text { cal hazard }\end{array}$ & $\begin{array}{l}\text { The product (raw mate- } \\
\text { rial, work in process } \\
\text { product, or finished } \\
\text { product) contains po- } \\
\text { tential hazard known as } \\
\text { Haram Substances }\end{array}$ \\
\hline B & $\begin{array}{l}\text { The process does not contain } \\
\text { a controlled step that pre- } \\
\text { vents, destroys or reduce } \\
\text { potential hazard to an ac- } \\
\text { ceptable level }\end{array}$ & $\begin{array}{l}\text { The process does not } \\
\text { contain a controlled } \\
\text { step that prevents, } \\
\text { destroys or remove } \\
\text { haram substances }\end{array}$ \\
\hline C & $\begin{array}{l}\text { There is possibility of con- } \\
\text { tamination during the pro- } \\
\text { cess }\end{array}$ & $\begin{array}{l}\text { There is possibility of } \\
\text { contamination during } \\
\text { the process }\end{array}$ \\
\hline D & $\begin{array}{l}\text { There is possibility of mis- } \\
\text { handling the product during } \\
\text { processing or distribution }\end{array}$ & $\begin{array}{l}\text { There is possibility of } \\
\text { mishandling the prod- } \\
\text { uct during the distribu- } \\
\text { tion or processing }\end{array}$ \\
\hline
\end{tabular}

\begin{tabular}{ll}
\multicolumn{2}{c}{ Table 2: Risk Level } \\
\hline $\begin{array}{l}\text { Risk } \\
\text { Level }\end{array}$ & Explanation \\
\hline 4 & Any four hazard characteristics (any four of A, B, C, and D). \\
3 & Any three hazard characteristics (any three of A, B, C, and \\
2 & D). \\
1 & Any two hazard characteristics (any two of A, B, C, and D). \\
0 & Any one hazard characteristics (any one of A, B, C, and D). \\
\hline
\end{tabular}

Table 3: Hazard Classification

\begin{tabular}{ll} 
& Table 3: \\
\hline Risk Level & Effect of Hazard \\
\hline$>3-4$ & high risk \\
$>2-3$ & medium risk \\
$>1-2$ & low risk \\
$0-1$ & very low risk \\
\hline
\end{tabular}

\section{Results and discussion}

A verified modular process flow diagram of ayam lalapan is presented in Fig. 1. There are six modules in the process of making ayam lalapan. Module 1 is related to material reception and material storage of frozen, chilled and ambient products. Module 2 is related to the preparation of frozen food. Module 3 is related to preparation of chilled food. Module 4 is related to preparation of ambient products. Module 5 is related to the cooking process. Lastly, module 6 is related to serving food.

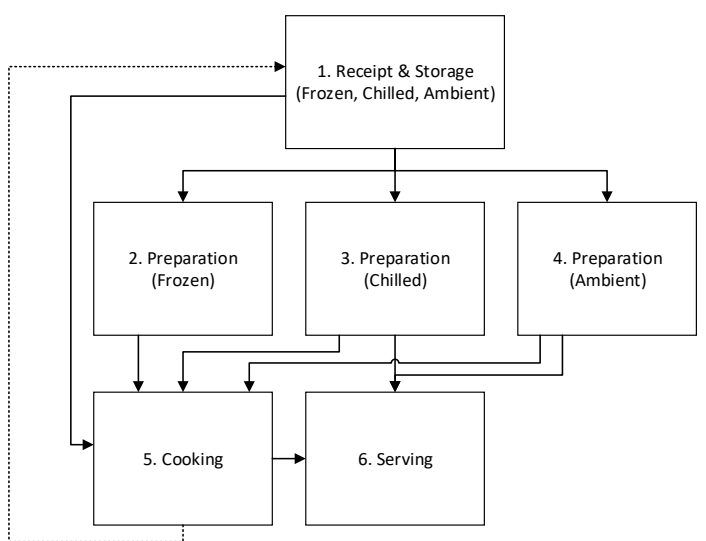

Fig. 1: Modular Process Flow Diagram of Ayam Lalapan.

\subsection{Hazard and haram analysis control chart}

Hazard and haram analysis is performed to analyze biological, chemical and physical hazard, as well as the presence of haram substances that may occur in the process steps endangering the food. The presence of hazards depends on the nature of the process, since each process does not always involve all four hazard categories (biological, chemical and physical hazards, and the presence of haram substances). First, we analyze the hazards in each process; there are thirty eight biological hazards, nine chemical hazards, six physical hazards and five presences of haram substances found in the food processing of ayam lalapan. The biological hazard is contributed by the possibility of proliferation of pathogens, cross contamination with other materials, and survival of pathogens caused by inadequate heat treatment. The chemical hazard is caused by some pesticides left on the vegetables. The physical hazard is caused by the possible presence of pests, and foreign materials such as plastic, debris, and human body parts. The presence of haram substances is caused by the possibility of the delivered products not meeting the Halal dietary requirements. Table 4 shows a summary of the process's potential hazards.

Table 4: Process Step and Its Associated Potential Hazard on the Process of Making Ayam Lalapan

\begin{tabular}{ll}
\hline Potential Hazard & Process Step \\
\hline & $1.1 \mathrm{a}, 1.1 \mathrm{~b}, 1.1 \mathrm{c}, 1.1 \mathrm{e}, 1.1 \mathrm{f}, 1.2,1.3,1.4$, \\
& $1.5 \mathrm{a}, 1.5 \mathrm{~b}, 1.5 \mathrm{c}, 1.5 \mathrm{~d}, 1.6,1.7,2.1,2.2$, \\
Biological Hazard & $2.3,2.4,3.1,3.2,3.3,3.4,3.5,3.6,3.7$, \\
& $3.8,4.1,4.2,4.3,4.4,4.5,4.6,5.1,5.2$, \\
& $5.3,5.4,6.1,6.2$ \\
Chemical Hazard & $1.1 \mathrm{~b}, 1.1 \mathrm{c}, 1.5 \mathrm{a}, 3.1,3.2,3.3,4.3,4.4,4.5$ \\
Physical Hazard & $1.7,4.1,4.2,5.2,5.2,5.3$ \\
Presence of Haram Substance & $1.1 \mathrm{a}, 1.1 \mathrm{~b}, 1.1 \mathrm{c}, 1.1 \mathrm{~d}, 1.1 \mathrm{e}$ \\
\hline
\end{tabular}

After analyzing the hazards in each process, the next step is measuring the significance of the hazard by modifying the hazard characteristics proposed by NACMCF, to determine the significance of potential hazards. The risk level is calculated by calculating the number of hazard characteristics on each potential hazard. For example, the risk level of biological hazard in the process 1.1a is three because there are three hazard characteristics in this hazard. The guidance of the risk level scoring can be seen in Table 2. Similarly, the risk level for the presence of haram substance is two. Finally, we can calculate the risk level of the process step 1.1a by averaging the associated risk levels on the process 1.1a then we get 1.25. Based on Table 3, we can interpret the risk level of process $1.1 \mathrm{a}$ as low risk because the value of risk level falls between $>1-2$.

Furthermore, control measures are also identified to ensure that the potential hazards can be controlled, eliminated, or reduced to an acceptable level. Lacking a prerequisite program, the construction of HHACCP can be accommodated by including a personal 
hygiene program and pest control program into the control measures. For example, the processes that involve direct contact with humans, such as transferring the goods, moving them to the clean container, peeling off the spices, and chopping are managed by personal hygiene program. The pest control program is to ensure that that no pests can enter and spoil the food. A pest control program can be started by eliminating any standing water around the kitchen as well as any shelter where pests can breed and survive. Furthermore, we need to seal all openings, cracks and holes. Additional tools such as bug zapper or glue boards can be used to ensure the safety of the food.

These three analyses: hazard and haram analysis, hazard evaluation, and identification of control measures, are summarized in Table A.1, a hazard and haram analysis control chart.

\subsection{Hazard and haram critical control point}

Raw material CCPs (Critical Control Points) decision tree [6, 7] and a process step decision tree ${ }^{[8]}$ are used to determine the critical control points in the process of making ayam lalapan. Mean- while, the raw material and process step HCCPs (Halal Critical Control Points) decision tree ${ }^{[1]}$ is used to determine the Halal critical control points. The raw material and process HCCP decision tree, raw material $\mathrm{CCP}$ decision tree, and summary of the process step CCP decision tree can be seen in Table 5, Table 6, and Table 7, respectively.

Based on the process step decision tree, there are six CCPs have been found in the food processing of ayam lalapan. These CCPs are mainly caused by the possible proliferation of pathogens and survival of pathogens during the cooking process. Freezing and chilling at certain temperatures prevent the proliferation of pathogens and keep the products fresh. Cooking at certain temperature is suggested to kill the pathogens in the products. According to HCCPs decision tree, there is only one HCCP has been found in the process of making ayam lalapan. Vegetables, spices and tempe are Halal critical control points but unable to certify. Halal critical points and critical control points can be seen in Table 8 .

Table 1: Raw Material and Process HCCP Decision Tree

\begin{tabular}{|c|c|c|c|c|c|c|c|c|c|}
\hline $\begin{array}{l}\text { Process } \\
\text { Step }\end{array}$ & Raw material & $\begin{array}{l}\text { Q1. Do all } \\
\text { product raw } \\
\text { materials } \\
\text { have halal } \\
\text { certification? }\end{array}$ & $\begin{array}{l}\text { Q2. Is there } \\
\text { any possibility } \\
\text { for cross con- } \\
\text { tamination of } \\
\text { haram } \\
\text { susbtances? }\end{array}$ & $\begin{array}{l}\text { Q3. Are } \\
\text { the non- } \\
\text { certified } \\
\text { products } \\
\text { are being } \\
\text { used in } \\
\text { the pro- } \\
\text { cess? }\end{array}$ & $\begin{array}{l}\text { Q4. Do the } \\
\text { materials } \\
\text { contain any } \\
\text { haram sub- } \\
\text { stances? }\end{array}$ & $\begin{array}{l}\text { Q5. is there } \\
\text { specific } \\
\text { production } \\
\text { line and } \\
\text { storage area } \\
\text { for certified } \\
\text { and non- } \\
\text { certified } \\
\text { process and } \\
\text { ingredients } \\
\text { clearly dedi- } \\
\text { cated? }\end{array}$ & $\begin{array}{l}\text { Q6. Could } \\
\text { the sanita- } \\
\text { tion proce- } \\
\text { dure able to } \\
\text { eliminate } \\
\text { the fat, } \\
\text { smell, } \\
\text { colour and } \\
\text { taste } \\
\text { (dibagh)? }\end{array}$ & $\begin{array}{l}\text { Q7 : Is there } \\
\text { any potential } \\
\text { cross contami- } \\
\text { nation of ha- } \\
\text { ram substanc- } \\
\text { es? }\end{array}$ & $\mathrm{HCCP}$ \\
\hline \multirow{3}{*}{1.1} & Meat and egg & Yes & No & - & - & - & - & - & \multirow{3}{*}{$\begin{array}{l}\text { No } \\
\text { Yes } \\
\text { (Unable } \\
\text { to certi- } \\
\text { fy) } \\
\text { No }\end{array}$} \\
\hline & $\begin{array}{l}\text { Vegetables, } \\
\text { spices, and } \\
\text { tempe }\end{array}$ & No & - & $\begin{array}{l}\text { Yes } \\
\text { (Unable } \\
\text { to certify) }\end{array}$ & - & - & - & - & \\
\hline & Seasoning & Yes & No & - & - & - & - & - & \\
\hline
\end{tabular}

Table 2: Raw Material Ccp Decision Tree

\begin{tabular}{|c|c|c|c|c|}
\hline Raw material & $\begin{array}{l}\text { Q1. Is there a significant } \\
\text { hazard associated with } \\
\text { this raw material? }\end{array}$ & $\begin{array}{l}\text { Q2. Are you or the customer } \\
\text { going to process this hazard } \\
\text { out of the product? }\end{array}$ & $\begin{array}{l}\text { Q3. Is there a cross- } \\
\text { contamination risk to the facili- } \\
\text { ty or to other products which } \\
\text { will not be controlled? }\end{array}$ & $\mathrm{CCP}$ \\
\hline Presence of pathogens & Yes & Yes & No & No \\
\hline \multicolumn{5}{|l|}{ Vegetables, Spices } \\
\hline Pesticide residual & Yes & Yes & No & No \\
\hline Bacteria & Yes & Yes & No & No \\
\hline Tempe (Bacteria) & Yes & Yes & No & No \\
\hline Egg (Salmonella Enteritidis) & Yes & Yes & No & No \\
\hline
\end{tabular}

Table 3: Summary of Process Step CCP Decision Tree

\begin{tabular}{|c|c|c|c|c|c|c|c|}
\hline Process Step & $\begin{array}{l}\text { Q1. Is there } \\
\text { a significant } \\
\text { hazard at } \\
\text { this process } \\
\text { step }\end{array}$ & $\begin{array}{l}\text { Q2. Do } \\
\text { control } \\
\text { measure(s) } \\
\text { exist for the } \\
\text { identified } \\
\text { hazard? }\end{array}$ & $\begin{array}{l}\text { Q2a. Is } \\
\text { control } \\
\text { necessary } \\
\text { at this step } \\
\text { for safety? }\end{array}$ & $\begin{array}{l}\text { Q3. Is this step } \\
\text { specifically } \\
\text { designed to } \\
\text { eliminate or } \\
\text { reduce the likely } \\
\text { occurrence of } \\
\text { the hazard to an } \\
\text { acceptable lev- } \\
\text { el? }\end{array}$ & $\begin{array}{l}\text { Q4. Could con- } \\
\text { tamination occur } \\
\text { at, or increase, to } \\
\text { unacceptable } \\
\text { level(s)? }\end{array}$ & $\begin{array}{l}\text { Q5. Will a } \\
\text { subsequent } \\
\text { step or action } \\
\text { eliminate or } \\
\text { reduce the } \\
\text { hazard to an } \\
\text { acceptable } \\
\text { level? }\end{array}$ & $\mathrm{CCP}$ \\
\hline 1.3 Store frozen & Yes & Yes & - & Yes & - & - & Yes \\
\hline 1.5a Store chilled (vegetables) & Yes & Yes & - & Yes & - & - & Yes \\
\hline $1.5 \mathrm{~b}$ Store chilled (tempe) & Yes & Yes & - & Yes & - & - & Yes \\
\hline 1.5c Store chilled (chopped vegetables) & Yes & Yes & - & Yes & - & - & Yes \\
\hline $1.5 \mathrm{~d}$ Store chilled (cooked meat) & Yes & Yes & - & Yes & - & - & Yes \\
\hline 5.4 Cook According to recipe & Yes & Yes & - & Yes & - & - & Yes \\
\hline
\end{tabular}

\subsection{Establish halal critical limits and critical limits}

The identified Halal critical control points and critical control points are then analyzed to determine the associated critical limits. These limits are called critical limits and are used to differentiate between safe and unsafe operating conditions. Since Halal food must meet Halal dietary requirements, the Halal critical limits must be zero for any kind of haram substances.

HCCP1 is the possible presence of haram substances on the vegetables, spices and tempe. Although all vegetables and spices do 
not have the Halal logo, they are still permitted by Halal dietary requirements as long as the vegetables and spices are not poisonous, intoxicating or dangerous to health [3]. Tempe, as a derivative product from soybeans, is Halal too. So, we need to ensure that the suppliers only use vegetables and spices those are not contaminated with other products. Keeping a good relationship and good communication with suppliers is important to gain transparency from the supplier. Also, we need to encourage the supplier to do the Halal practice correctly. To ensure that both supplier and restaurant do the Halal practice, the availability of Halal food certification in our business can assure the consumer that all the served food meet Halal dietary requirements. In Taiwan, we can apply for Halal certification from external institution, such as in Taiwan Halal Integrity Development Association (THIDA) [9].

CCP 1 is keeping the food frozen. The freezer temperature must be at $00 \mathrm{~F}(-17.80 \mathrm{C})$. Keeping the products in a frozen state inhibits the proliferation of pathogens in the meat.

CCP 2, 3, 4 and 5 are related to the chilling process. The chiller temperature must be at $400 \mathrm{~F}$ (4.40C) or below. Similar to keeping products in a frozen state, keeping products at chilled temperature inhibits the proliferation of pathogens in the vegetables, tempe, chopped vegetables and cooked meat.

CCP 6 is related to the cooking process. Cooking the products at a certain temperature is suggested to ensure that the food is safe and free of pathogens. The cooking process is a method to kill the surviving pathogens inside the product. Table 8 shows the critical limits on each HCCP and CCP.

\subsection{Establish monitoring procedures and corrective actions}

Monitoring procedures are established at every CCP and HCCP to ensure that the established critical limits are achieved and maintained. Corrective actions should also be determined to ensure that the established control measures are done, and to eliminate any deviations during the process. Table 8 shows the monitoring procedures and corrective actions which should be taken on each $\mathrm{HCCP}$ and CCP.

\subsection{Documentation, verification procedures, and record keeping}

Afterwards, the developed HHACCP control chart must be verified periodically or every time a process or method is changed. The first step of verification procedures is carried out by verifying the process flow diagram. Furthermore, verification of a comprehensive HHACCP system should also be performed annually. These verification activities are to ensure that both the methods and procedures are implemented accurately and effectively.

Documentation and record keeping provide evidence that the constructed HHACCP plan is maintained and implemented according to the plan. Record keeping includes the CCP monitoring results, and the finding of losses or deviations and their associated corrective actions. Documentation includes the hazard and haram analysis control chart and HHACCP control chart.

\subsection{Comparison between before and after improvement}

In order to see the difference in risk level before and after improvement, the current condition at the restaurant is compared to the proposed control measures. For example, the risk level of the current condition in the process $1.1 \mathrm{a}$ is 1.25 , but after the proposed control measures (e.g. freezing the product as soon as possible, cooking the product at a later step, checking the halal label, and frequently auditing the supplier) are conducted, the risk level on process $1.1 \mathrm{a}$ can be reduced to 0.25 . Table 9 shows hazard and haram analysis of process 1.1a after the condition is improved.

In Table 9 we can see that process 1.1a is no longer has a presence of haram substance as a hazard. Since the restaurant has applied the proposed control measures, which is checking the Halal label and frequently auditing supplier, the hazard now has control step. Although preventive actions have been taken, there is still a chance of biological hazard occurrence since meat very easily becomes contaminated. Therefore, we assign "one" on the hazard characteristic A. The way to ensure that the hazard can be controlled is by frequently auditing the suppliers, and checking whether the suppliers have the proper conditions to prevent this biological hazard from proliferating. After receiving the meat, the way the restaurant can control the hazard is to inhibit the proliferation of biological hazards by cooking it at the later step.

Then, the total risk level of ayam lalapan processing after the condition is improved can be calculated by averaging the risk level on each process step. As shown in Fig. 2, the total risk level of the current condition for ayam lalapan processing has been reduced by $75.64 \%$ to 0.29 , which can be interpreted as very low risk.

Table 8: Hhaccp Control Chart

\begin{tabular}{|c|c|c|c|c|c|c|c|c|c|}
\hline No. & Process & $\begin{array}{l}\text { Potential } \\
\text { Hazard }\end{array}$ & $\begin{array}{l}\text { Control } \\
\text { Measure }\end{array}$ & Critical limits & Monitoring & $\begin{array}{l}\text { Monitoring } \\
\text { Frequency }\end{array}$ & $\begin{array}{l}\text { Monitoring } \\
\text { responsibil- } \\
\text { ity }\end{array}$ & $\begin{array}{l}\text { Corrective } \\
\text { Action }\end{array}$ & $\begin{array}{l}\text { Corrective } \\
\text { Action } \\
\text { Responsibil- } \\
\text { ity }\end{array}$ \\
\hline HCCP 1 & $\begin{array}{l}\text { Check the } \\
\text { incoming } \\
\text { Ingredient: } \\
\text { Vegetables, } \\
\text { spices, and } \\
\text { Tempe }\end{array}$ & $\begin{array}{l}\text { Haram sub- } \\
\text { stances }\end{array}$ & $\begin{array}{l}\text { - The suppli- } \\
\text { er must be } \\
\text { chosen cor- } \\
\text { rectly and } \\
\text { frequently } \\
\text { audited } \\
\text { - Avoid any } \\
\text { non-Halal } \\
\text { products }\end{array}$ & $\begin{array}{l}\text { Reject prod- } \\
\text { ucts if they } \\
\text { do not meet } \\
\text { the halal } \\
\text { requirements }\end{array}$ & $\begin{array}{l}\text { Check the } \\
\text { supplier }\end{array}$ & 1 week & $\begin{array}{l}\text { Chef / } \\
\text { Restaurant } \\
\text { owner }\end{array}$ & $\begin{array}{l}\text { - Reject } \\
\text { products } \\
\text { - Change } \\
\text { supplier }\end{array}$ & $\begin{array}{l}\text { Chef / Res- } \\
\text { taurant } \\
\text { owner }\end{array}$ \\
\hline CCP 1 & $\begin{array}{l}1.3 \text { Store } \\
\text { frozen }\end{array}$ & $\begin{array}{l}\text { Possible } \\
\text { proliferation } \\
\text { of pathogens }\end{array}$ & $\begin{array}{l}\text { Ensure one } \\
\text { container is } \\
\text { not loaded } \\
\text { with too } \\
\text { much meat } \\
\text { so that all } \\
\text { parts of the } \\
\text { meat can stay } \\
\text { frozen }\end{array}$ & $\begin{array}{l}\text { Ensure the } \\
\text { freezer tem- } \\
\text { perature is at } \\
0^{\circ} \mathrm{F}(- \\
\left.17.8^{\circ} \mathrm{C}\right)\end{array}$ & $\begin{array}{l}\text { - Check the } \\
\text { temperature } \\
\text { using ther- } \\
\text { mometer } \\
\text { - Frequently } \\
\text { calibrate the } \\
\text { thermometer }\end{array}$ & $\begin{array}{l}1 \text { hour } \\
1 \text { month }\end{array}$ & Chef & $\begin{array}{l}\text { Check the } \\
\text { products } \\
\text { and call } \\
\text { repairman } \\
\text { to fix the } \\
\text { refrigera- } \\
\text { tor }\end{array}$ & Chef \\
\hline $\mathrm{CCP} 2$ & $\begin{array}{l}1.5 \text { a Store } \\
\text { chilled (vege- } \\
\text { tables) }\end{array}$ & $\begin{array}{l}\text { Possible } \\
\text { proliferation } \\
\text { of pathogens }\end{array}$ & $\begin{array}{l}\text { - Ensure one } \\
\text { container is } \\
\text { not loaded } \\
\text { with too } \\
\text { much vege- } \\
\text { tables so that } \\
\text { all parts of } \\
\text { the vegeta- } \\
\text { bles can stay }\end{array}$ & $\begin{array}{l}\text { Ensure the } \\
\text { chiller tem- } \\
\text { perature is at } \\
40^{\circ} \mathrm{F} \\
\left(4.4^{\circ} \mathrm{C}\right) \text { or } \\
\text { below }\end{array}$ & $\begin{array}{l}\text { - Check the } \\
\text { temperature } \\
\text { using ther- } \\
\text { mometer } \\
\text { - Frequently } \\
\text { calibrate the } \\
\text { thermometer }\end{array}$ & $\begin{array}{l}1 \text { hour } \\
1 \text { month }\end{array}$ & Chef & $\begin{array}{l}\text { Check the } \\
\text { products } \\
\text { and call } \\
\text { repairman } \\
\text { to fix the } \\
\text { refrigera- } \\
\text { tor }\end{array}$ & Chef \\
\hline
\end{tabular}




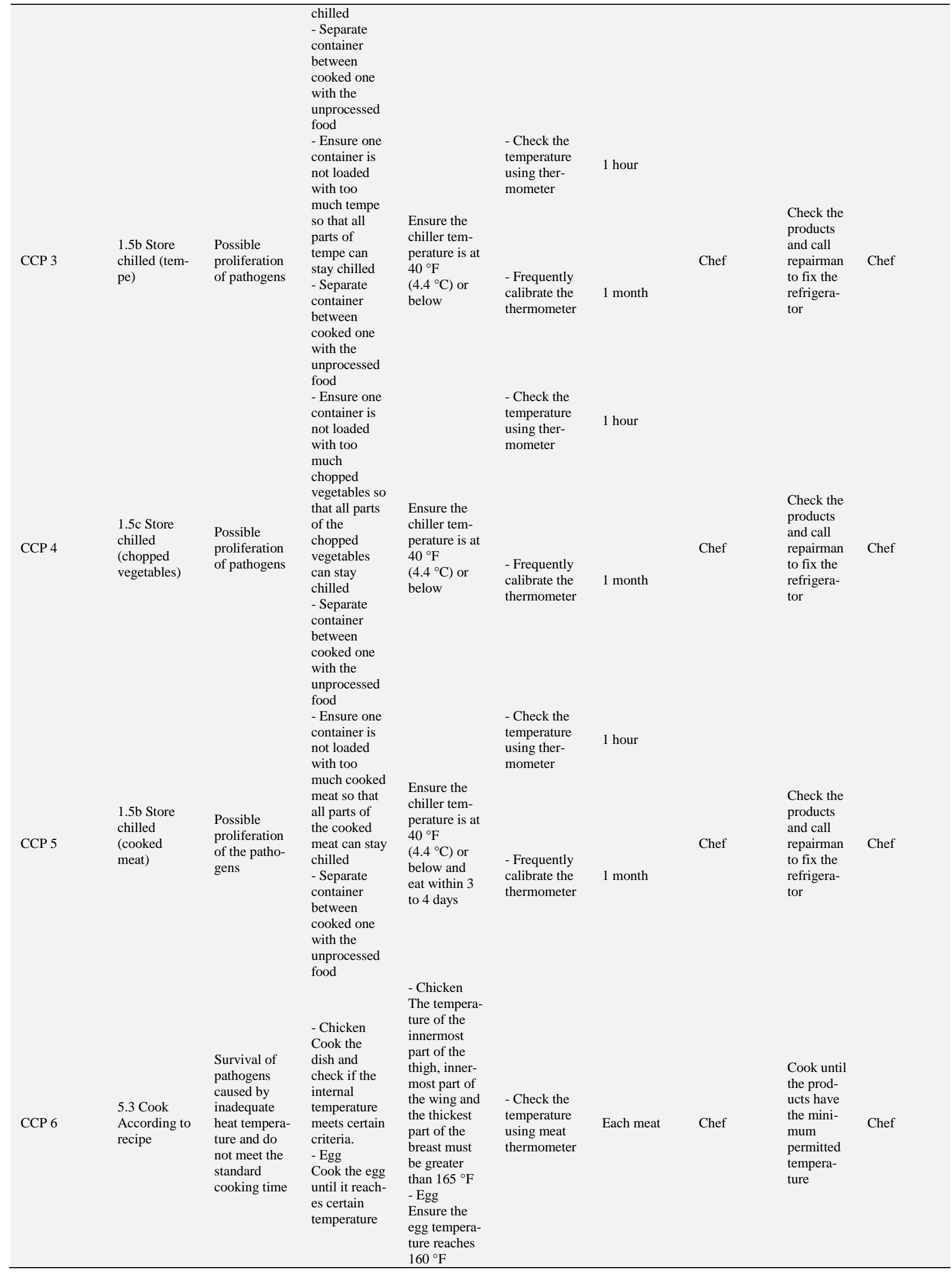


Table 9: Hazard and Haram Analysis of Process 1.1a (After Improvement)

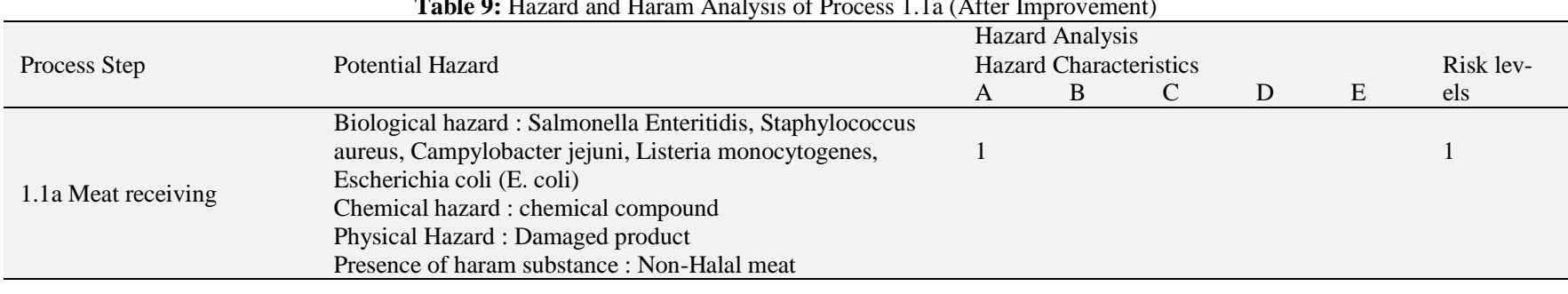

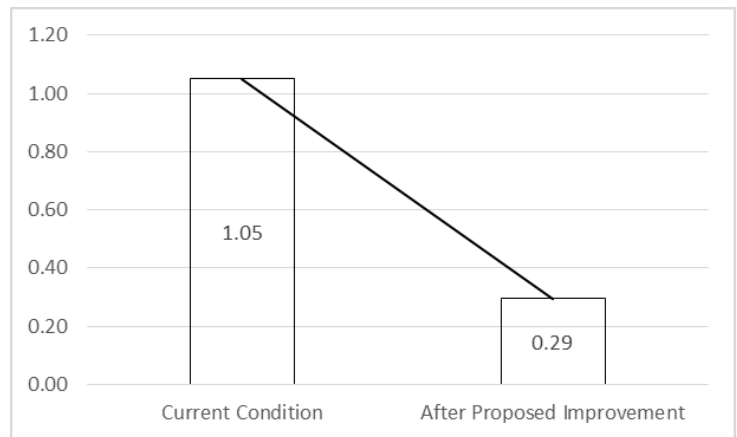

Fig. 2: Risk Level Before and after Improvement.

\section{Conclusion}

This study found that Halal dietary requirements can be incorporated into the regular HACCP and used to analyze the process in catering service to ensure that the delivered food meets Halal dietary requirements. HHACCP methodology proposed by Kohilavani et al. (2013) had been implemented in the food processing of ayam lalapan at the Indonesian Halal Restaurant in Taipei, and we found that the risk level of the current condition is low, with the index of 1.05. The proposed control measures can reduce the risk level by $75.64 \%$ to 0.29 , which is considered as very low risk.

\section{References}

[1] Kohilavani et al. (2013) Embedding Islamic Dietary Requirements into HACCP approach. Food Control, 34(2), 607-612. http://dx.doi.org/10.1016/j.foodcont.2013.06.008.

[2] Pew Research Center. (2015) the Future of World Religions: Population Growth Projections, 2010-2050. [Online] Available from: http://www.pewforum.org/2015/04/02/religious-projections-20102050/ [Accessed: 21th April 2015].
[3] MS 1500:2009 (2009). Halal food - Production, preparation, handling and storage - General Guidelines (2nd Revision). Department of Standards Malaysia.

[4] Mortimore, S. and Wallace C. (2013) HACCP: A Practical Approach. 3rd ed. US: Springer. http://dx.doi.org/10.1007/978-14614-5028-3.

[5] Pierson, M.D. and Corlett, D.A. (ed.) (1992) HACCP: Principles and Applications. New York: Chapman \& Hall.

[6] Mortimore, S. E. and Wallace, C. A. (1994) HACCP: A Practical Approach. London: Chapman \& Hall. http://dx.doi.org/10.1007/978-1-4615-2063-4.

[7] Mortimore, S. E. and Wallace, C. A. (1998) HACCP: A Practical Approach, Second Edition. Gaithersburg: Aspen Publishers Inc. (Springer). http://dx.doi.org/10.1007/978-1-4615-5781-4.

[8] Codex (Joint FAO/WHO Food Standards Program, Codex Alimentarius Commission) (2009b) Food Hygiene (Basic Texts), 4th Ed. Hazard analysis and critical control point (HACCP) system and guidelines for its application. Rome: Food and Agriculture Organizations of the United Nations.

[9] Department of Islamic Development Malaysia (JAKIM). (2016) List of Approved International Bodies. [Online] Available from: http://www.halal.gov.my/v4/index.php/en/badan-islam/badan-luarnegara-diiktiraf. [Accessed: 11th January 2016].

\section{Appendix A}

\section{Hazard and haram analysis control chart}

Table A.1: Hazard and Haram Analysis Control Chart

\begin{tabular}{|c|c|c|c|c|c|c|c|}
\hline Process Steps & Potential Hazards & $\begin{array}{l}\text { Hazard A } \\
\text { Hazard C } \\
\text { A } \\
\text { Contain } \\
\text { Hazard }\end{array}$ & $\begin{array}{l}\text { lysis } \\
\text { racteristics } \\
\text { B } \\
\text { No Control Step }\end{array}$ & $\begin{array}{l}\text { C } \\
\text { Contamination during process }\end{array}$ & $\begin{array}{l}\text { D } \\
\text { Mishandling the product }\end{array}$ & Risk Level & $\begin{array}{l}\text { Control } \\
\text { Measures }\end{array}$ \\
\hline \multicolumn{8}{|c|}{$\begin{array}{l}\text { Module } 1 \text { - Receipt and Storage } \\
1.1 \text { Check the incoming raw materials }\end{array}$} \\
\hline \multirow[t]{4}{*}{ a. Meat } & $\begin{array}{l}\text { Biological haz- } \\
\text { ard : Salmonella } \\
\text { Enteritidis, } \\
\text { Staphylococcus } \\
\text { aureus, Campyl- } \\
\text { obacter jejuni, } \\
\text { Listeria mono- } \\
\text { cytogenes, Esch- } \\
\text { erichia coli (E. } \\
\text { coli) }\end{array}$ & 1 & 1 & 1 & & 3 & $\begin{array}{l}\text { - Freeze the } \\
\text { product as } \\
\text { soon as } \\
\text { possible } \\
\text { - Cooking } \\
\text { the product } \\
\text { in later step } \\
\text { - Frequently } \\
\text { audit the } \\
\text { supplier }\end{array}$ \\
\hline & Chemical hazard & & & & & 0 & \\
\hline & Physical Hazard & & & & & 0 & \\
\hline & $\begin{array}{l}\text { Presence of } \\
\text { haram sub- } \\
\text { stance : Non- } \\
\text { Halal meat }\end{array}$ & 1 & 1 & & & 2 & $\begin{array}{l}\text { - Check the } \\
\text { halal label- } \\
\text { Frequently } \\
\text { audit the } \\
\text { supplier }\end{array}$ \\
\hline
\end{tabular}


Biological hazard : Bacteria (E.Coli)

b. Vegetables

Chemical haz-

a : Pesticide

residual

- Wash the

product in

latter step

- Separate

the vegeta-

bles from

other foods

such as raw

meat, poultry

or seafood

- Cooking

the product

in later step

- Wash the

product in

latter step

- Frequently

audit the

Physical Hazard

supplier

Presence of

haram sub-

stance : Cross

contamination

with non-Halal

products in the

supplier

Biological haz-

ard : Bacteria

(E.Coli)

c. Spices

Chemical haz-

ard : Pesticide

residual

- Ensure the

origin of the

products

- Frequently

audit the

supplier

- Wash the

product in

latter step

- Separate

the vegeta-

bles from

other foods

such as raw

meat, poultry

or seafood

- Cooking

the product

in later step

- Wash the

product in

latter step-

Frequently

audit the

supplier

Physical Hazard

Presence of

haram sub-

stance : Cross

contamination

with non-Halal

products in the

supplier

Biological hazard

Chemical hazard

Physical Hazard

d. Seasoning Presence of

Presence of
haram sub-

haram sub-
stance : Non-

Halal seasoning

- Ensure the

origin of the

products-

Frequently

audit the

supplier

- Ensure the

origin of the

products-

Frequently

audit the

supplier

- Wash the

product in

latter step

- Separate

the vegeta-

bles from

other foods

such as raw

meat, poultry

or seafood

- Cooking

the product

in later step

Chemical hazard

Physical Hazard

0

Presence of

haram sub-

stance : Non-

Halal seasoning

Ensure the

origin of the

products

- Frequently

audit the

supplier

- Cooking

the product

Biological haz-

f. Egg

ard : Salmonella

in later step

- Frequently

audit the

supplier 


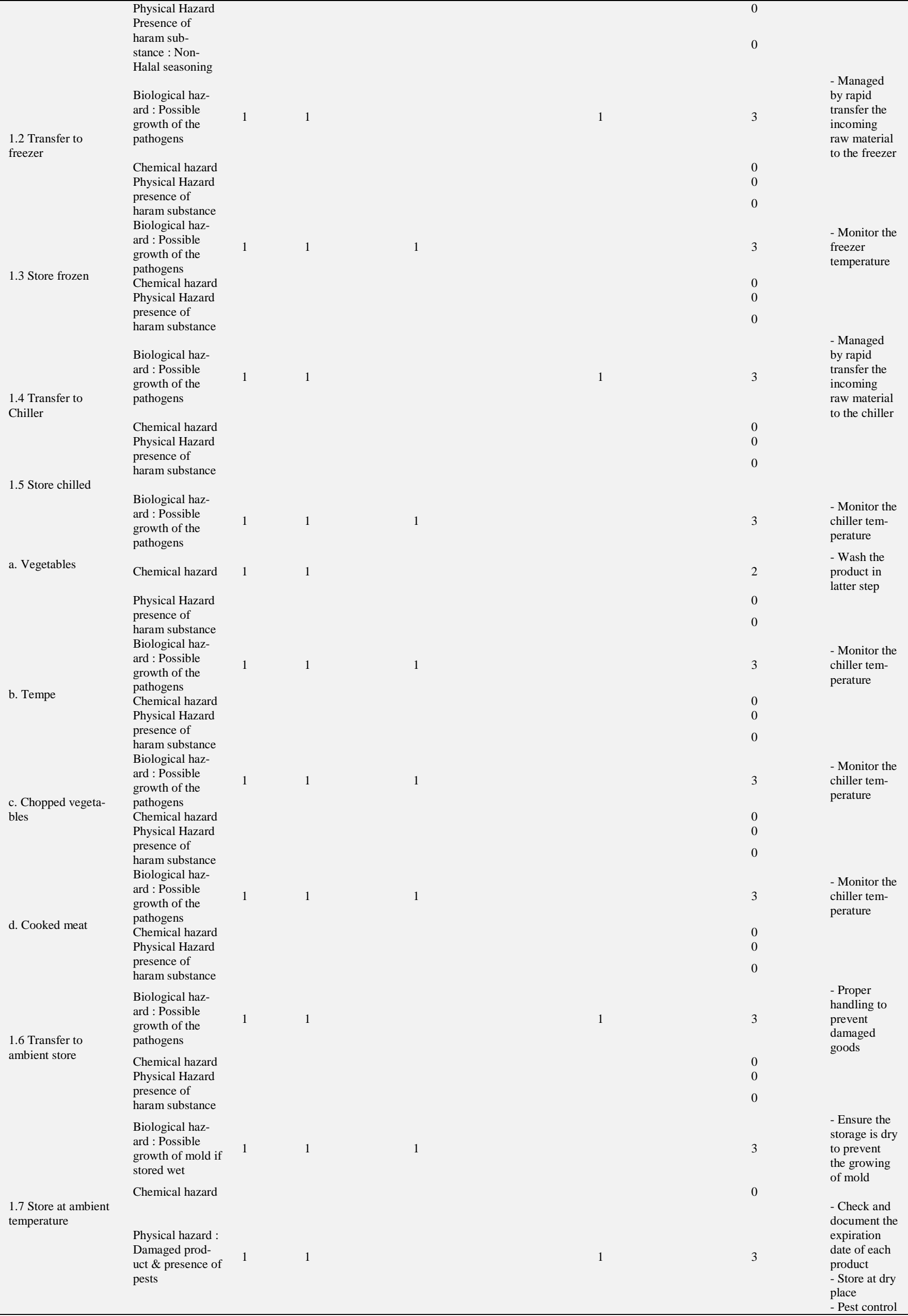


presence of

haram substance

program

Module 2 - Preparation (Frozen)

Biological hazard : Possible growth of the

2.1 Transfer raw pathogens

meat to the kitchen Chemical hazard Physical Hazard presence of haram substance

Biological hazard : Possible growth of the

2.2 Defrosting pathogens
- Rapid transfer to the kitchen for cooking

process

Three ways

to thaw

chicken:

1. In the

refrigerator

May take 1

to 2 days or

longer to

thaw

2. In cold

water

Submerge

the chicken

in cold

water,

changing the

water every

30 minutes

to be sure it

stays cold (2

to 3 hours).

Cook imedi-

ately after

thawing

3 . In the

microwave

Should be

cooked

immediately

after thawing

Chemical hazard

Physical Hazard

presence of

haram substance

Biological haz-

ard : Contamina-

tion with patho-

gens

Chemical hazard

Physical Hazard

presence of

haram substance

Biological haz-

ard : Possible

cross contamina-

tion with other

2.4 Chopping the

tion with other
materials

Chemical hazard

Physical Hazard

presence of

haram substance

Module 3 - Preparation (Chilled)

Biological haz-

ard : Possible

growth of the

pathogens

3.1 Transfer vegeta-

bles to kitchen table

Chemical haz-

ard : Pesticide is

left in the vege-

tables

Physical Hazard

presence of

haram substance

Biological haz-

ard : Possible

cross contamina-

tion with other

3.2 Chopping the

materials

Chemical haz

ard : Pesticide is

left in the vege-

Physical Hazard
0

0

- Wash the

meat by

using flow-

ing water

- Segregation

of cutting

board and

knives
- Managed

by rapid

transfer the

vegetables to

the kitchen

- Managed

by personal

hygiene

program

- Wash the

product in

latter step

0

- Segregation

of cutting

board and

knives

- Wash the

product in

latter step 


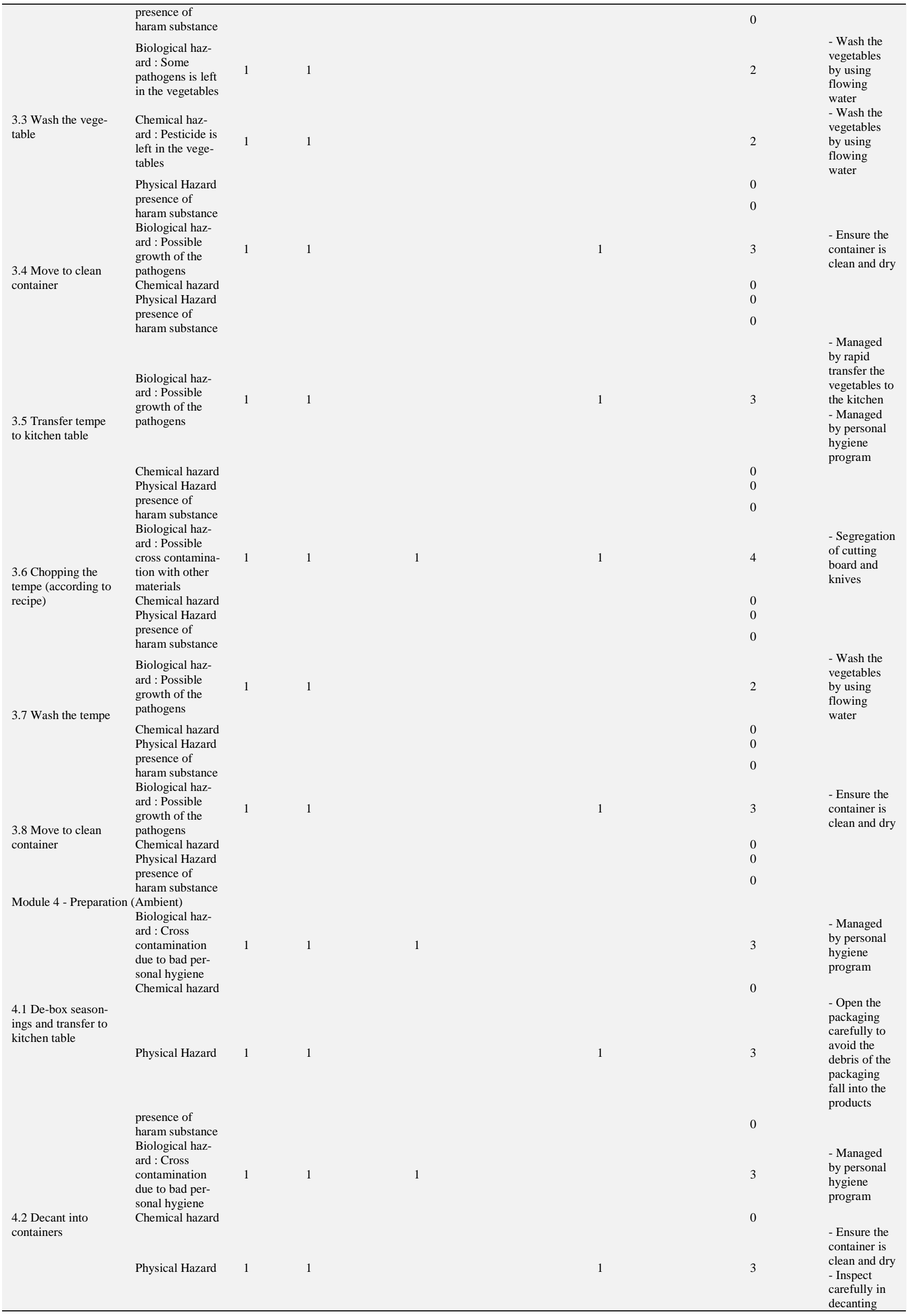




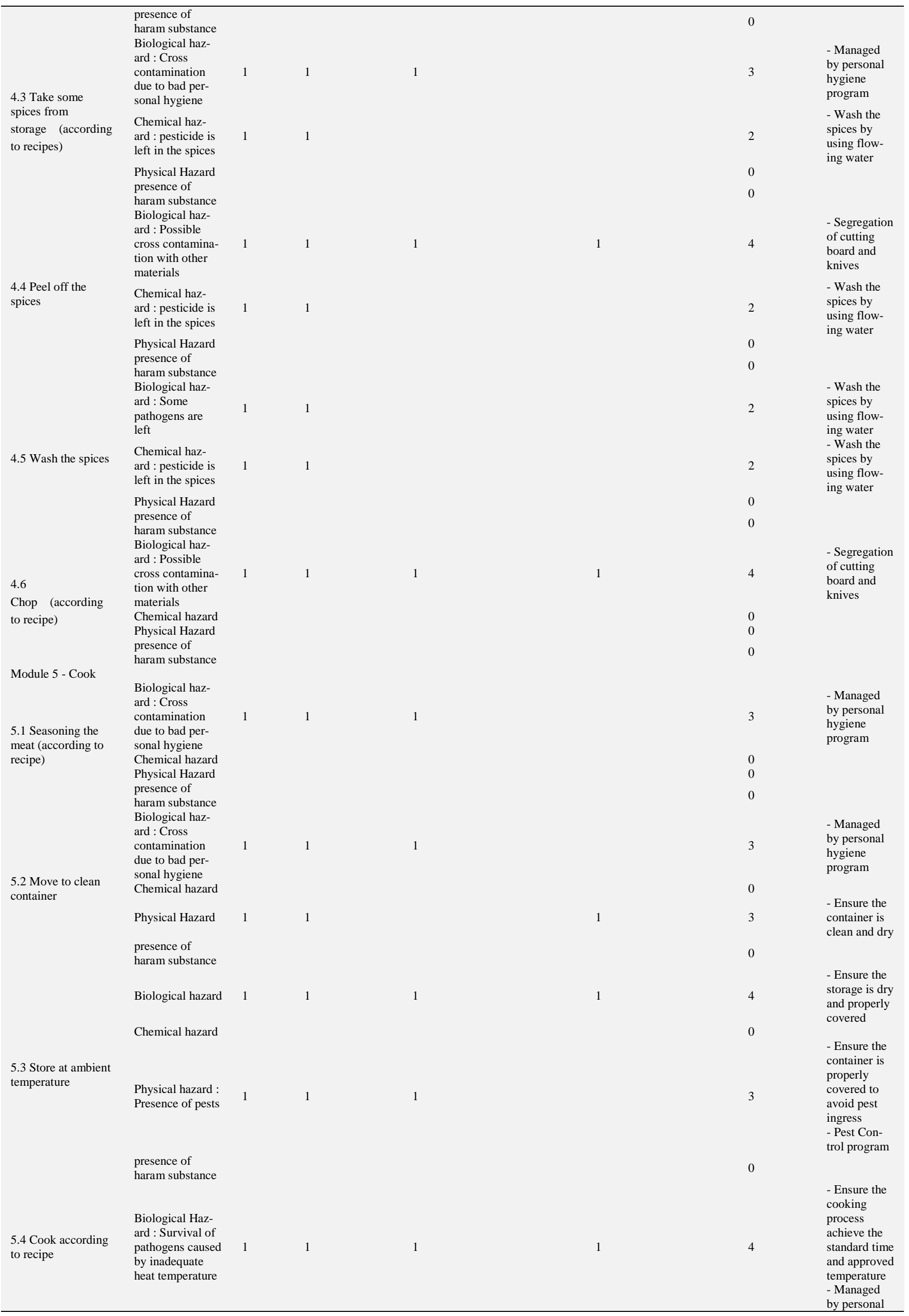




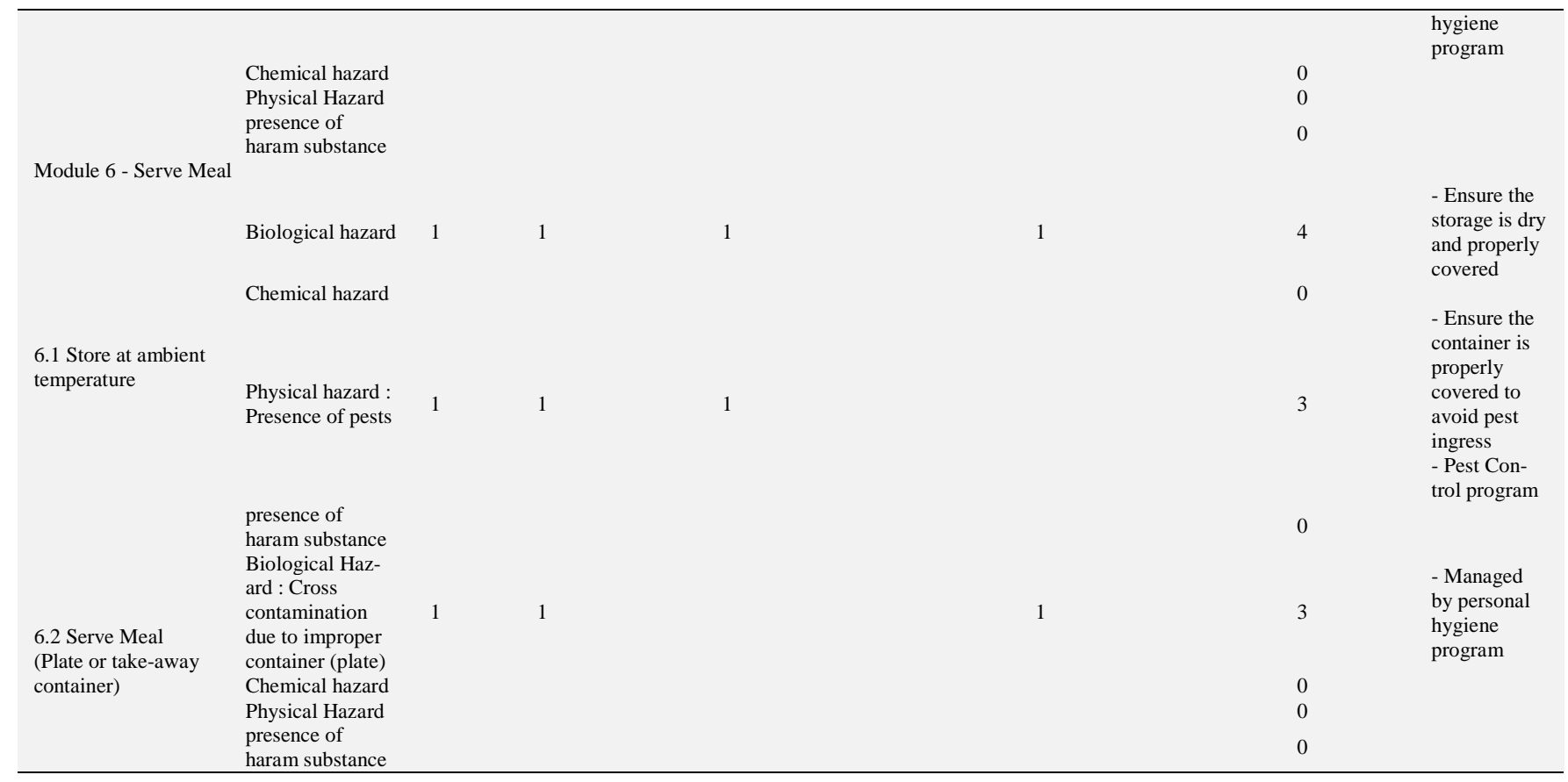

